\title{
CORRESPONDENCE
}

\section{THE OCCURRENCE OF DETERMINABLE PLANTS IN THE LOWER ESTUARINES OF PETERBOROUGH}

SIR,-The Estuarine clays of the East Midlands have long been known to contain a few plant fragments. In 1939 (Geol. Mag., lxxvi, 478-489) Murray described some microfossils (Lycopod megaspores) from 6 out of 8 Upper Estuarine localities, but 7 Lower Estuarine clays proved barren.

The occurrence of a flora of determinable fragments from the Lower Estuarine near Peterborough is therefore new. Two samples provided rather different floras, though the plants were preserved in the same way as isolated shreds of cuticle or isolated spores, plainly having suffered biological maceration before they were finally deposited. The only preparation needed is to disintegrate the dried clay with hot water.

The discovery of a root bed in this district (beneath the River Nene at Wansford N.G.R. 077994) penetrating into the strata of the uppermost Lias (Jurense zone) indicates that this area was colonized by land plants very possibly during the time of deposition of the Lower Estuarine rocks.

The first sample (dredging at N.G.R. 077994) from the River Nene at Wansford is a blackish clay. It yielded great numbers of minute fragments of leaves, the commonest is a species of Ginkgo but there is also a species of Otozamites. Both genera are widespread in Middle Jurassic floras and the species are scarcely determinable from such material. There are, however, several species of excellently preserved Lycopod megaspores which make very satisfactory and easily separated species. Some of these (e.g. Triletes sparassis) occur throughout the Yorkshire Estuarine Series, but another agrees with an undescribed species almost confined to the Lower Estuarines in Yorkshire (where it has been noted in 26 localities) and still others are new.

The second sample was removed from a pit at a depth of $10 \mathrm{ft}$. 5 in., near the New Mermaid, Wansford, and close to the origin of the first. It may be from nearly the same level, but its flora is different. It is full of charcoal, much of it representing burnt leaves and twigs and even pieces of Equisetum cones. The commonest cuticle belongs to a tiny Equisetum with stems 1-2 mm. thick; it is a species which has been met commonly as cuticle fragments from the Yorkshire Lower and Middle Estuarines but having never been seen except as cuticle fragments it is not worthy of a name. There are cuticles of some tough leaved conifers which have not been recognized, and again a number of megaspores, some apparently new to science.

It may be remarked that some pieces of sandy Limestone presumed to be the Lower Lincolnshire Limestone from the same locality provided plenty of waterworn charcoal (of tree origin) but no leaf fragments at all.

The occurrence of species in common with the Yorkshire flora is not surprising, but it is interesting that this flora is not merely an attenuated version of the Yorkshire one, but has some different species. The difference is significant because the Yorkshire Estuarine microfossils have been studied in some $\mathbf{4 0 0}$ localities, fully half of which yielded megaspores.

This find is published, not so much as an advance, but to call attention to a feature of these rather unpromising beds which might offer considerable scope for future study. Such plant microfossils are easily obtainable, and the spores in particular make attractive little specimens which it seems are well zoned and can be readily sorted into species.

JOHN L. GILBERT.

TOM M. HARRIS.

THE UNIVERSITY,

READING.

19th February, 1953. 